OPEN ACCESS

Approved by:

Frontiers Editorial Office,

Frontiers Media SA, Switzerland

${ }^{*}$ Correspondence:

Frontiers Production Office

pharmacology.production.office@

frontiersin.org

Specialty section:

This article was submitted to

Pharmacology of Anti-Cancer Drugs,

a section of the journal

Frontiers in Pharmacology

Received: 13 August 2021

Accepted: 13 August 2021

Published: 31 August 2021

Citation:

Frontiers Production Office (2021)

Erratum: Mcl-1 Inhibition: Managing Malignancy in Multiple Myeloma.

Front. Pharmacol. 12:758130.

doi: 10.3389/fphar.2021.758130

\section{Erratum: Mcl-1 Inhibition: Managing Malignancy in Multiple Myeloma}

\author{
Frontiers Production Office * \\ Frontiers Media SA, Lausanne, Switzerland
}

Keywords: multiple myeloma, drug resistant, Mcl-1, Bcl-2 homology 3 mimetics, apoptosis

\section{An Erratum on}

Mcl-1 Inhibition: Managing Malignancy in Multiple Myeloma

by Al-Odat, O. S., von Suskil, M., Chitren, R. J., Elbezanti, W. O., Srivastava, S. K., Budak-Alpddogan, T., Jonnalagadda, S. C., Aggarwal, B. B., and Pandey, M. K. (2021) Front. Pharmacol. 12:699629. doi: 10.3389/fphar.2021.699629

Due to a production error, several author names were incorrectly written. The names of Omar S. AlOdat, Robert J. Chitren, Weam O. Elbezanti, Sandeep K. Srivastava, Subash C. Jonnalagadda, and Bharat B. Aggarwal had their initials mistakenly omitted.

The publisher apologizes for this mistake.

Copyright $\odot 2021$ Frontiers Production Office. This is an open-access article distributed under the terms of the Creative Commons Attribution License (CC BY). The use, distribution or reproduction in other forums is permitted, provided the original author(s) and the copyright owner(s) are credited and that the original publication in this journal is cited, in accordance with accepted academic practice. No use, distribution or reproduction is permitted which does not comply with these terms. 